\title{
Aktivitas Sitotoksik Ekstrak Etanol, Fraksi Etanol-Air, Etil Asetat serta N-Heksana Buah Pare (Momordica Charantia) pada Sel MCF-7 secara In-Vitro
}

\section{Cytotoxic Activity of Ethanol, Ethanol-Water, Ethyl Acetate, and N- Hexane Extracts of Momordica Charantia Against MCF-7 Cells In- Vitro}

\author{
Adhe Retnantya Pamungkas, Peni Indrayudha* \\ Fakultas Farmasi, Universitas Muhammadiyah Surakarta, Jl A Yani Tromol Pos I, Pabelan, Kartasura, \\ Sukoharjo 57162 \\ *E-mail: peni.indrayudha@ums.ac.id
}

Received: 16 Oktober 2019; Accepted: 26 Desember 2019; Published: 27 Desember 2019

\begin{abstract}
Abstrak
Buah pare merupakan salah satu buah mempunyai khasiat salah satunya sebagai antikanker yang aktif pada sel kanker payudara MCF-7. Penelitian ini bertujuan untuk membandingkan potensi aktivitas sitotoksik antara ekstrak etanol buah pare dengan hasil fraksi etanol, etil asetat serta n- heksana terhadap sel kanker payudara MCF-7 serta untuk mengetahui golongan senyawa yang terkandung dalam masing-masing sampel. Serbuk buah pare diekstraksi dengan metode maserasi menggunakan pelarut etanol $80 \%$ kemudian dilanjutkan dengan fraksinasi dengan metode partisi cair- cair menggunakan pelarut n-heksana, etil asetat dan etanol 96\%air. Hasil ekstrak dan fraksi diuji sitotoksik dengan metode MTT assay. Hasil uji sitotoksik menunjukkan bahwa bahwa ekstrak etanol $80 \%$ buah pare memiliki aktivitas sitotoksik yang tidak poten. Fraksi etil asetat dengan konsentrasi tertinggi $16 \mu \mathrm{g} / \mathrm{mL}$ memiliki daya hambat yang paling tinggi yaitu sebesar $43,87 \%$ populasi sel MCF-7. Ekstrak dan fraksi diuji skrining fitokimia dengan metode Kromatografi Lapis Tipis (KLT). Hasil deteksi menunjukkan fraksi n-heksana terdapat lebih banyak golongan senyawa daripada ekstrak etanol, fraksi etanol-air dan fraksi etil asetat.
\end{abstract}

Kata Kunci: MTT assay, MCF-7, Momordica charantia

\begin{abstract}
Bitter melon is one of fruit that have pharmacological effects such as an anticancer which potentially active on breast cancer cell MCF-7. The aim of this study was to compare the potential cytotoxic activity between ethanol extract of pare and the results of ethanol, ethyl acetate and n-hexane fraction on MCF-7 breast cancer cells and to determine the class of compounds contained in each sample. Pare's powder was extracted with maceration method in $80 \%$ ethanol solvent and then continue to fractionated in $96 \%$ ethanol, ethyl acetate and hexane solvent. Extract and fractions were continue to cytotoxic assay using the MTT assay method. Cytotoxic test results showed that the ethanolic extract had no potential cytotoxic activity. Ethyl acetate fraction with the highest concentration $16 \mu \mathrm{g} / \mathrm{mL}$ has the highest potential inhibition 43,87\% on MCF-7 cells population. Extract and fractions than continue to phytochemical screening with Thin Layer Chromatography (TLC) method. TLC detection showed that n-hexane fraction contained more compound groups than ethanolic extract, ethanolic-water fraction and ethyl acetate fraction.
\end{abstract}

Keywords: MTT assay, MCF-7, Momordica charantia

\section{PENDAHULUAN}

Negara berkembang seperti Indonesia memiliki persentase kematian akibat kanker yang cukup tinggi yaitu sekitar $70 \%$. Tingginya persentase tersebut dikarenakan rendahnya layanan pengobatan bagi pasien kanker. Layanan pengobatan kanker yang tersedia di Indonesia hanya sekitar 30\%. Fakta ini didukung dengan kecilnya ketersediaan obat kanker di masyarakat hanya sekitar 45 jenis pada tahun 2013 (Departemen Kesehatan Republik Indonesia, 2013 dan Sudoyo, 2017). Laporan pengeluaran biaya pada bulan juni tahun 2017 menunjukkan bahwa BPJS (Badan 
Penyelenggara Jaminan Sosial) telah mengeluarkan biaya pengobatan kanker sebanyak 6,3 triliun (Kementrian Kesehatan Republik Indonesia, 2018). Tahun 2018 BPJS telah memutuskan untuk tidak membiayai terapi bagi pasien kanker yang menggunakan obat Traztuzumab, namun tetap menanggung penuh terapi kanker yang menggunakan obat sesuai dengan yang tercantum dalam formularium (Arnani, 2018). Fakta ini akan semakin membebani pasien, terutama pasien kanker dari kalangan masyarakat kurang mampu yang menggunakan obat tersebut sebagai terapi kanker. Melihat kondisi tersebut, saat ini sangat diperlukan pengembangan suatu obat kanker baru yang lebih terjangkau sehingga mampu meringankan beban masyarakat meskipun secara tidak langsung masih diperlukan aplikasi, contohnya dengan memanfaatkan buah pare.

Buah pare merupakan salah satu buah yang memiliki banyak manfaat secara farmakologis (Thomasset et al., 2007 dan Yin et al., 2008). Salah satu khasiatnya adalah anti-karsinogenik (Huang et al., 2008). Buah ini mengandung berbagai komponen bioaktif yang kaya akan aktivitas farmakologis (Jia et al., 2017). Hasil penelitian menunjukkan bahwa aktivitas sitotoksik ekstrak etanol 50\% buah pare mampu menghambat pertumbuhan sel kanker payudara MCF-7 dengan $\mathrm{IC}_{50} 0,77$ $\mu \mathrm{g} / \mathrm{mL}$ (Vishwanath et al., 2015). Penelitian lain tentang fraksinasi dari ekstrak buah pare kini telah dikembangkan, fraksi crude flavonoid ekstrak etanol buah pare memiliki aktivitas sitotoksik yang signifikan dengan $\mathrm{LC}_{50} \quad 12,38 \mu \mathrm{g} / \mathrm{mL}$ terhadap sel kanker pankreas MiaPaCa2 (Barua et al., 2014). Konstituen bioaktif yang terkandung seperti cucurbitane type terpenoid, glikosida triterpen, serta beberapa komponen hasil isolasi seperti kuguacin $\mathrm{J}$, karaviloside XI, kuguaglikosida C, momordicosid Q-U, charantin, $\alpha$ - momorcharin, dan MAP30 (Dandawate et al., 2017). Buah pare juga mengandung senyawa yang memiliki aktivitas sitotoksik seperti taikuguasin $\mathrm{C}$, taikuguasin
D, charantagenin D, goyaglikosid, charantagenin E, momordikosid $\mathrm{K}$, asam 3,7diokso-23,24,25,26,27-pentanorcucurbit-5en-22-oat, 25,26,27-trinorcucurbit-5-ene3,7,23-trione, cucurbitacin B dan stigmasta7,25(27)-dien-3 $\beta$-ol. Taikugausin $\mathrm{C}$ serta taikugausin $\mathrm{D}$ yang diperoleh dari ekstrak etanol buah pare memiliki aktivitas sitotoksik terhadap sel kanker payudara MCF-7 masingmasing memiliki $\mathrm{ED}_{50} 42,60 \mu \mathrm{M}$ dan 42,66 $\mu \mathrm{M}$ (Liaw et al., 2015). Charantagenin D dan goyaglikosid diperoleh dari ekstrak etanol buah pare memiliki aktivitas sitotoksik yang lebih poten terhadap sel kanker glioblastoma U87 daripada charantagenin E, momordikosid $\mathrm{K}$ dan stigmasta-7,25(27)-dien-3 $\beta$-ol, charantagenin D memiliki $\mathrm{IC}_{50}$ sebesar 1,08 $\mu \mathrm{mol} / \mathrm{L}$ dan goyaglikosid sebesar $0,19 \mu \mathrm{mol} / \mathrm{L}$ (Wang et al., 2012). Asam 3,7-diokso23,24,25,26,27-pentanorcucurbit-5-en-22-oat dan 25,26,27-trinorcucurbit-5-ene-3,7,23trione yang diperoleh dari ekstrak metanol buah pare memiliki aktivitas sitotoksik terhadap sel kanker hati HepG2 dengan $\mathrm{IC}_{50}$ $>100 \mu \mathrm{M}$ (Hen et al., 2010). Cucurbitacin B diperoleh dari ekstrak etanol buah pare dan memiliki aktivitas sitotoksik terhadap sel kanker pankreas HPDE dan MiaPaCa2 dengan $\mathrm{GI}_{50}$ masing- masing $939,1 \mu \mathrm{g} / \mathrm{mL}$ dan $516,5 \mu \mathrm{g} / \mathrm{mL}$ (Richmond et al., 2017).

Buah pare telah terbukti secara ilmiah mengandung berbagai macam isolat yang memiliki khasiat berbeda-beda. Isolat yang berhasil diperoleh dari ekstrak etanol buah pare seperti taikuguasin $\mathrm{C}$ terbukti memiliki aktivitas sitotoksik yang aktif terhadap sel MCF-7. Melihat potensi aktivitas sitotoksik ekstrak etanol buah pare yang menjanjikan, namun belum terdapat data yang memuat aktivitas sitotoksik hasil fraksinasinya seperti fraksi etanol, etil asetat serta n-heksana. Sehingga sangat diperlukan suatu penelitian untuk mengetahui potensi aktivitasnya terutama pada sel kanker payudara MCF-7. Hal ini di karenakan karakteristik dari sel MCF-7 yang kurang agresif, tidak invasif, memiliki potensi metastatis yang rendah serta merupakan salah satu sel yang paling sering 
dikembangkan dalam sebuah penelitian (Comşa et al., 2015).

\section{METODE PENELITIAN \\ Bahan}

Bahan utama yang digunakan pada tahap preparasi sampel adalah buah pare yang kulitnya berwarna hijau muda yang diperoleh dari Pasar Boloh, Toroh, Grobogan, Jawa Tengah, selanjutnya dicuci dengan $10 \mathrm{~L}$ akuades. Ekstraksi membutuhkan bahan seperti serbuk pare yang telah halus, etanol 96\% serta akuades. Fraksinasi membutuhkan bahan seperti ekstrak etanol buah pare, etanol $96 \%$, etil asetat, n-heksana serta akuades. Uji sitotoksik membutuhkan bahan seperti sel kanker payudara MCF-7 koleksi Laboratorium Kultur Sel Mamalia Fakultas Farmasi UMS, SDS (sodium dodesil sulfat), PBS (phosphate buffer saline), akuades, media kultur DMEM, tripsin-EDTA (tripsin 0,025\%), DMSO serta larutan MTT. Skrining fitokimia membutuhkan bahan berupa ekstrak etanol, fraksi etanol-air, fraksi etil asetat, fraksi n-heksana, fase gerak (etil asetat dan nheksana), reagen semprot (sitroborat, Liebermann Burchard, anisaldehid- $\mathrm{H}_{2} \mathrm{SO}_{4}$, Dragendorff, dan $\mathrm{FeCl}_{3}$ ).

\section{Preparasi sampel}

Buah pare ditimbang lalu dicuci dengan akuades sebanyak $10 \mathrm{~L}$ hingga bersih dari pengotor seperti debu dan tanah. Buah pare kemudian dibelah dan dihilangkan bijinya. Buah pare selanjutnya dipotong menjadi berbentuk dadu dengan ukuran $\pm 1 \times 1 \mathrm{~cm}$ dengan tujuan untuk mempercepat dan mempermudah proses pengeringan, selanjutnya dikeringkan dalam oven dengan suhu $40^{\circ} \mathrm{C}$ selama 6 jam. Potongan buah pare yang telah kering selanjutnya dibuat serbuk dengan menggunakan blender. Serbuk buah pare disimpan dalam plastik kedap udara lalu diletakkan pada kulkas dengan suhu $4^{\circ} \mathrm{C}$ (Budrat and Shotipruk, 2008).

\section{Ekstraksi}

Ekstraksi dilakukan dengan metode maserasi, menggunakan pelarut etanol $80 \%$ dengan perbandingan pelarut 1:4 dalam volume $2 \mathrm{~L}$. Proses ekstraksi dan remaserasi masing-masing berlangsung selama 4 hari. Evaporasi dilakukan dengan menggunakan rotary evaporator pada suhu $80^{\circ} \mathrm{C}$ sampai pelarutnya menguap sempurna, penguapan yang sempurna ditandai dengan berhentinya tetesan pelarut yang tertampung dalam rotary evaporator. Penguapan dilanjutkan di atas waterbath selama 9-14 hari untuk mendapatkan ekstrak yang lebih kental. Kekentalan tersebut dapat dilihat dari viskositas ekstrak saat cawan porselin yang berisi ekstrak dibalik dan ekstrak tidak tumpah/mengalir.

\section{Fraksinasi}

Fraksinasi dilakukan dengan menggunakan metode partisi cair-cair. Sebanyak $10 \mathrm{~g}$ ekstrak etanol dilarutkan dalam $25 \mathrm{~mL}$ akuades ditambah etanol $96 \% 10 \mathrm{~mL}$ pada cawan porselin di atas waterbath. Larutan ekstrak dimasukkan dalam corong pisah lalu ditambahkan etanol $96 \%$ sebanyak $25 \mathrm{~mL}$ dan $25 \mathrm{~mL}$ akuades sehingga volume akhir larutan ekstrak adalah $85 \mathrm{~mL}$. Pemisahan yang pertama kali dilakukan dengan pelarut n-heksana sebanyak $50 \mathrm{~mL}$, kemudian digojok dan ditampung dalam Erlenmeyer $250 \mathrm{~mL}$. Penambahan n-heksana dilakukan sampai 4 kali. Fraksinasi yang kedua menggunakan pelarut etil asetat. Sisa larutan ekstrak etanol yang sudah selesai digojog dengan pelarut n-heksana kemudian ditambahkan $50 \mathrm{~mL}$ etil asetat, dan diulangi sampai 4 kali. Etanol dan etil asetat saat dicampurkan tidak menunjukkan adanya pemisahan, agar pemisahan terlihat jelas, 
ditambahkan $50 \mathrm{~mL}$ akuades lalu digojog dan ditampung dalam Erlenmeyer yang berbeda. Evaporasi dilakukan menggunakan rotary evaporator pada suhu $60-80^{\circ} \mathrm{C}$. Fraksi nheksana mampu mengental dengan sempurna tanpa perlu diuapkan di atas waterbath, sedangkan fraksi etil asetat dan etanol-air perlu mendapatkan perlakuan di atas waterbath selama 1-3 jam untuk mendapatkan fraksi yang lebih kental. Seluruh fraksi ditampung dalam botol coklat, ditutup rapat dan disimpan dalam suhu ruangan.

\section{Uji Sitotoksik dengan Metode MTT Assay}

Uji sitotoksik diawali dengan proses panen sel. Panen kultur sel dilakukan saat sudah mencapai $80 \%$ konfluen. Kultur sel dikatakan $80 \%$ konfluen saat sudah tumbuh merata pada permukaan plate dan membentuk monolayer. Proses selanjutnya adalah perhitungan sel yang diawali dengan pengambilan $10 \mu \mathrm{L}$ sel lalu dimasukkan ke dalam hemasitometer kemudian dilakukan perhitungan sel di bawah mikroskop. Sel kemudian dipindahkan ke conical tube sesuai dengan hasil perhitungan selanjutnya ditambahkan media DMEM hingga $10 \mathrm{~mL}$. Sebanyak $100 \mu \mathrm{L}$ suspensi sel MCF-7 dipindahkan ke dalam plate 96 well (disisakan 4 sumuran kosong sebagai kontrol media) lalu diinkubasi selama 7 hari (Junedi et al., 2009). Kontrol positif yang digunakan adalah Methothrexat $10 \mathrm{mM}$ (Fodor et al., 2016). Kontrol perlakuan mengandung 5 seri konsentrasi ekstrak etanol $80 \%$ buah pare $(15,63 ; 31,25 ; 62,5 ; 125 ; 250 \mu \mathrm{g} / \mathrm{mL})$, fraksi etanol-air, fraksi etil asetat, fraksi n-heksana $(1 ; 2 ; 4 ; 8 ; 16 \mu \mathrm{g} / \mathrm{mL})$, media DMEM serta sel MCF-7. Larutan kontrol perlakuan dibuat dengan melarutkan $10 \mathrm{mg}$ ekstrak etanol dan ketiga fraksi dalam tabung mikro $1,5 \mathrm{~mL}$, selanjutnya dilarutkan dengan $100 \mu \mathrm{L}$ larutan DMSO hingga larut sempurna kemudian ditambahkan $900 \mu \mathrm{L}$ media DMEM (Dulbecco's Modified Eagle Medium) yang mengandung penisilin-streptomisin $1 \mathrm{~mL}$ dan 10\% (10 mL) FBS (Fetal Bovine Serum). Inkubasi dilakukan selama 48 jam dalam inkubator $\mathrm{CO}_{2}$ pada suhu $37^{\circ} \mathrm{C}$.

Uji sitotoksik dilakukan dengan metode MTT. Sel yang masih hidup akan bereaksi dengan reagen MTT dengan membentuk warna ungu. Pembacaan absorbansi dilakukan menggunakan alat ELISA reader dengan $\lambda$ $550 \mathrm{~nm}$. Hasil absorbansi yang diperoleh selanjutnya digunakan untuk menghitung persentase sel hidup. Berdasarkan data persentase sel hidup dibuat plot antara log konsentrasi sampel dengan persentase sel hidup sehingga diperoleh parameter $\mathrm{A}, \mathrm{B}, \mathrm{r}$ dari persamaan regresi linier $\mathrm{y}=\mathrm{Bx}+\mathrm{A}$. Nilai $\mathrm{IC}_{50}$ diperoleh dari antilog $\mathrm{x}$ persamaan regresi linier tersebut (Putri, 2013).

\section{Skrining Fitokimia}

Skrining fitokimia dilakukan untuk mendeteksi golongan senyawa yang terkandung di dalam sampel dengan metode Kromatografi Lapis Tipis (KLT). Fase diam yang digunakan adalah silika F254. Fase gerak yang digunakan dalam ekstrak etanol, fraksi etanol-air serta fraksi etil asetat adalah etil asetat:n-heksana dengan perbandingan 7:3 sedangkan fraksi n-heksana menggunakan fase gerak n- heksana:etil asetat dengan perbandingan 8:2 Golongan senyawa yang akan dideteksi antara lain flavonoid (sitroborat) (Andersen and Markham, 2005), steroid (Lieberman-Burchard) (Farnsworth, 1966), fenolik dan tannin $\left(\mathrm{FeCl}_{3}\right)$ (Wardhani and Sulistyani, 2012), alkaloid (Dragendorff) dan terpenoid (anisaldehid- $\mathrm{H}_{2} \mathrm{SO}_{4}$ ) (Saifudin, 2014). Skrining fitokimia yang ideal dilakukan dalam kondisi lempeng KLT ukurannya sama dan mendapatkan perlakuan yang sama, penotolan sampel dan proses elusi KLT dilaksanakan secara bersamaan. 


\section{HASIL DAN PEMBAHASAN Preparasi Sampel}

Bobot total buah pare segar yang digunakan adalah $\pm 10 \mathrm{~kg}$ dan setelah dicuci, dibuang bijinya kemudian dipotong menjadi potongan yang lebih kecil, bobot daging buah pare sebesar 8,5 kg. Biji pare dibuang karena biji pare tidak termasuk dalam sampel penelitian. Pemotongan buah pare dengan ukuran yang kecil bertujuan untuk memperluas permukaan pare serta untuk memudahkan saat proses pengeringan. Bobot total simplisia yang diperoleh sebesar 498,57 g. Simplisia tersebut kemudian dihaluskan menggunakan blender, proses ini bertujuan agar senyawa-senyawa yang terkandung di dalam buah pare dapat terekstraksi dengan maksimal dengan semakin luasnya permukaan simplisia. Bobot serbuk pare yang diperoleh adalah 477,84 g. Terdapat perbedaan jumlah bobot antara simplisia dan serbuk pare, hal ini dikarenakan selama proses pembuatan serbuk terdapat serbuk yang saat dituangkan ke dalam wadah.

\section{Ekstraksi}

Serbuk pare selanjutnya diekstraksi dan diperoleh bobot total ekstrak sebesar 70,80 g dengan rendemen ekstrak sebesar 14,82\%. Nilai rendemen ekstrak etanol $80 \%$ buah pare 5 kali lebih banyak jika dibandingkan dengan rendemen ekstrak etanol $96 \%$ buah pare (Afifah, 2017). Perbedaan nilai rendemen mungkin disebabkan oleh perbedaan pelarut, perbedaan volume pelarut serta perbedaan lamanya ekstraksi. Ekstrak etanol 80\% memiliki karakteristik berwarna coklat kehitaman dan sangat lengket. Ekstrak disimpan di dalam eksikator, karena saat disimpan di dalam kulkas ekstrak akan mengeras dan sukar untuk dilarutkan.

\section{Fraksinasi}

Ekstrak etanol buah pare selanjutnya difraksinasi. Total volume fraksi etanol-air 75 $\mathrm{mL}$, fraksi etil asetat $250 \mathrm{~mL}$ serta fraksi $\mathrm{n}$ heksana $200 \mathrm{~mL}$. Volume fraksi etanol-air paling sedikit karena pada fraksi etanol-air volume yang digunakan hanya sebanyak 50 $\mathrm{mL}$ dan tidak dilakukan penambahan secara berulang. Meningkatnya volume fraksi etil asetat, hal ini disebabkan karena etil asetat dan etanol saat disatukan bercampur sempurna karena keduanya memiliki kepolaran yang mirip, sehingga ada sebagian etanol yang ikut tercampur bersama etil asetat. Total bobot fraksi etanol-air, etil asetat serta n- heksana setelah dievaporasi adalah 9,8 g; 0,08 g dan 0,12 g. Persentase rendemen dari masingmasing fraksi yaitu, fraksi etanol $98 \%$, fraksi etil asetat $0,8 \%$ dan fraksi n-heksana 1,2\%. Masing-masing fraksi memiliki karakteristik yang berbeda. Fraksi etanol memiliki sifat yang sedikit berbeda dengan ekstrak etanol. Fraksi etanol kental namun tidak lengket seperti ekstrak etanol. Fraksi etil asetat berwarna coklat jingga dengan tekstur encer. Fraksi n-heksana berwarna hijau dengan tekstur encer.

\section{Uji Sitotoksik}

Sel yang telah mendapatkan perlakuan ekstrak serta fraksi, diinkubasi, selanjutnya dilakukan uji sitotoksik. Uji sitotoksik memiliki prinsip reduksi garam kuning tetrazolium MTT dengan mekanisme reduktase. Reagen MTT akan bereaksi dengan suksinat dihidrogenase yang berasal dari mitokondria sel hidup yang mengakibatkan pecahnya cincin suksinat tetrazolium. Sel yang hidup membentuk kristal formazan berwarna ungu dan tidak larut air. Hasil uji sitotoksik menunjukkan bahwa hanya kontrol media saja yang berwarna kuning, dan sisanya berwarna ungu serta ungu kekuningan. Hasil ini menunjukkan bahwa sel yang mendapatkan perlakuan dan hasil uji MTTnya berwarna ungu maka tidak terdapat adanya kematian sel, namun pada sel yang mendapatkan perlakuan dan hasil uji MTTnya berwarna ungu kekuningan menunjukkan adanya kematian sel namun tidak maksimal. Persentase sel hidup dihitung kemudian dimasukkan ke dalam grafik dan dibuat persamaan regresi liniernya (lampiran), dari seluruh perlakuan tidak ada yang memiliki persentase sel hidup dibawah 50\%, sehingga hanya bisa ditentukan persentase sel yang mati. 
Tabel 1. Persentase sel hidup ekstrak etanol buah pare, fraksi etanol, etil asetat serta n-heksana pada sel kanker payudara MCF-7

\begin{tabular}{cccc}
\hline Sampel & Konsentrasi tertinggi & $\begin{array}{c}\text { Persentase sel } \\
\text { hidup (\%) }\end{array}$ & $\begin{array}{c}\text { Persentase } \\
\text { penghambatan }(\%)\end{array}$ \\
\hline Ekstrak etanol 80\% & $250 \mu \mathrm{g} / \mathrm{mL}$ & 124,03 & - \\
Fraksi etanol & $16 \mu \mathrm{g} / \mathrm{mL}$ & 77,20 & 22,80 \\
Fraksi etil astetat & $16 \mu \mathrm{g} / \mathrm{mL}$ & 56,13 & 43,87 \\
Fraksi n-heksana & $16 \mu \mathrm{g} / \mathrm{mL}$ & 77,20 & 22,80 \\
Kontrol positif metotreksat & $10 \mu \mathrm{M}$ & 71,70 & 28,30 \\
\hline
\end{tabular}

Hasil perhitungan persentase sel hidup (Tabel 1) sesuai dengan hasil dokumentasi mikroskopis, terlihat bahwa pada gambar yang mendapat perlakuan ekstrak tidak menunjukkan adanya kematian sel, namun pada sel yang mendapatkan perlakuan fraksi etanol, etil asetat, n-heksana serta kontrol positif metotreksat menunjukkan adanya kematian sel. Rendahnya aktivitas sitotoksik ekstrak etanol $80 \%$ buah pare berbanding terbalik dengan penelitian Vishwanath et al, yang menunjukkan bahwa ekstrak $50 \%$ buah pare memiliki aktivitas sitotoksik yang sangat poten pada sel kanker payudara MCF-7 (Vishwanath et al., 2015). Perbedaan ini dapat disebabkan oleh perbedaan konsentrasi pelarut yang digunakan. Semakin rendah konsentrasi etanol yang digunakan maka aktivitas sitotoksiknya akan semakin baik. Ekstrak etanol $80 \%$ pada penelitian sebelumnya oleh Raina et al mengandung senyawa fenolik yang cukup tinggi sehingga cenderung lebih cocok digunakan untuk uji aktivitas antioksidan (Raina et al., 2016). Potensi aktivitas sitotoksik fraksi etil asetat berbanding lurus dengan penelitian sebelumnya oleh Zahrah et al yang membahas tentang aktivitas sitotoksik fraksi etil asetat ekstrak etanol $70 \%$ buah pare terhadap sel HeLa dengan nilai $\mathrm{LC}_{50}$ sebesar $22,19 \mu \mathrm{g} / \mathrm{mL}$ (Zahrah et al, 2018). Fraksi etil asetat memiliki aktivitas penghambatan sel yang paling baik diantara sampel lainnya. Taikuguasin $\mathrm{C}$, taikuguasin $\mathrm{D}$ serta charantagenin D merupakan isolat ekstrak etanol buah pare yang memiliki aktivitas sitotoksik dengan struktur senyawa yang cenderung bersifat semi polar (Liaw et al., 2015 dan Wang et al., 2012). Ketiga isolat tersebut akan lebih tertarik dalam fraksi etil asetat karena fraksi etil asetat juga bersifat semi polar. Tingginya aktivitas sitotoksik fraksi etil asetat dapat disebabkan karena adanya senyawa-senyawa isolat yang memiliki aktivitas sitotoksik.

\section{Skrining Fitokimia}

Hasil skrining fitokimia dapat dilihat pada Tabel 2. Larutan ekstrak etanol dan larutan fraksi n-heksana, etil asetat dan etanolair selanjutnya dilakukan skrining fitokimia.

Tabel 2. Hasil skrining fitokimia ekstrak etanol, fraksi etanol, fraksi etil asetat serta fraksi n- heksana buah pare

\begin{tabular}{|c|c|c|c|c|c|}
\hline \multirow[b]{2}{*}{ Pereaksi } & \multicolumn{4}{|c|}{ Warna hasil deteksi sinar tampak } & \multirow[b]{2}{*}{ Senyawa } \\
\hline & $\begin{array}{c}\text { Ekstrak } \\
\text { etanol }\end{array}$ & $\begin{array}{c}\text { Fraksi } \\
\text { etanol-air }\end{array}$ & $\begin{array}{c}\text { Fraksi etil } \\
\text { asetat }\end{array}$ & $\begin{array}{l}\text { Fraksi n- } \\
\text { heksana }\end{array}$ & \\
\hline Sitroborat & Kuning & Kuning & Kuning & Hijau & Flavonoid \\
\hline Lieberman-burchard & Biru & Biru & Biru & Biru & Steroid \\
\hline Dragendorff & - & - & - & Coklat & Alkaloid \\
\hline Anisaldehid- $\mathrm{H}_{2} \mathrm{SO}_{4}$ & Ungu & Ungu & Ungu & Ungu & Terpenoid \\
\hline $\mathrm{FeCl}_{3}$ & - & - & - & Hitam & Fenol dan tanin \\
\hline
\end{tabular}



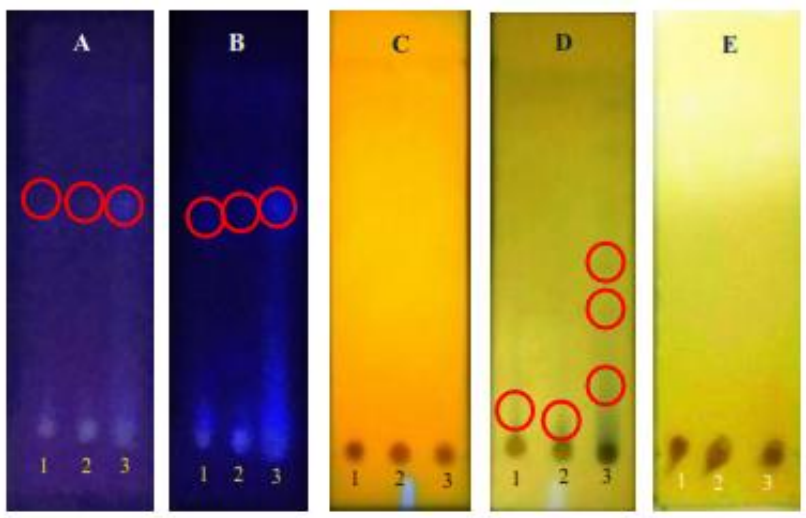

Gambar 1. Hasil skrining fitokimia ekstrak etanol (1), fraksi etanol (2) dan fraksi etil asetat (3) dengan fase gerak etil-asetat: $n$-heksana $(7: 3)$

Keterangan: (A) pereaksi sitroborat, (B) pereaksi Lieberman-burchard, A dan B diamati pada UV $366 \mathrm{~nm}$.

(C) pereaksi Dragendorff, (D) pereaksi anisaldehid- $\mathrm{H}_{2} \mathrm{SO}_{4}$, (E) pereaksi $\mathrm{FeCl}_{3 .} \mathrm{C}$, D, dan E diamati di bawah sinar UV $254 \mathrm{~nm}$

Berdasarkan hasil skrining fitokimia (Tabel 2), fraksi n-heksana mengandung 5 golongan senyawa dan ekstrak etanol, fraksi etanol-air serta fraksi etil asetat hanya mengandung 3 golongan senyawa.

Dokumentasi skrining fitokimia ekstrak etanol, fraksi etanol dan fraksi etil asetat (Gambar 1) menunjukkan adanya spot yang terdeteksi pada pereaksi sitroborat (A), Lieberman-burchard (B) dan anisaldehid$\mathrm{H}_{2} \mathrm{SO}_{4}$ (D). Kesimpulannya ekstrak etanol, fraksi etanol dan fraksi etil asetat mengandung golongan senyawa flavonoid, steroid dan terpenoid. Hasil penelitian ini kurang sesuai dengan penelitian sebelumnya (Supraja and
Usha, 2013 dan Ainia, 2017), karena tidak ditemukan golongan senyawa alkaloid pada ekstrak etanol. Komposisi fase gerak yang digunakan adalah etil asetat serta n-heksana dengan perbandingan 7:3, sehingga spot hasil elusi ekstrak etanol dan fraksi etanol sangat tipis dan tidak sejelas spot elusi fraksi etil asetat.

Dokumentasi skrining fitokimia fraksi nheksana (Gambar 2) menunjukkan bahwa terdapat spot elusi yang tampak saat plat disemprot dengan pereaksi sitroborat (A), Lieberman-burchard (B), dragendorff (C), anisaldehid- $\mathrm{H}_{2} \mathrm{SO}_{4}$ (D) dan $\quad \mathrm{FeCl}_{3}$ (E). Kesimpulannya fraksi n-heksana mengandung

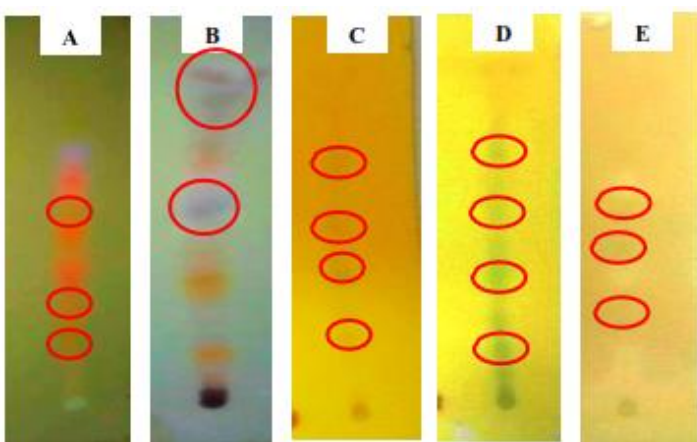

Gambar 2. Hasil skrining fitokimia fraksi n-heksana dengan fase gerak n-heksana:etil-asetat (8:2)

Keterangan : (A) pereaksi sitroborat, (B) pereaksi Lieberman-burchard, (C) pereaksi Dragendorff, (D) pereaksi anisaldehid-H2SO4, (E) pereaksi FeCl3. A,B,C, D dan E diamati di bawah UV 254 
5 golongan senyawa antara lain flavonoid, steroid, alkaloid, terpenoid, fenol dan tanin. Fraksi n-heksana mengandung lebih banyak senyawa karena n-heksana merupakan pelarut yang pertama kali difraksinasi sehingga lebih banyak senyawa yang terlebih dahulu tertarik di dalamnya dibandingkan fraksi yang lain. Tingginya aktivitas sitotoksik tidak tergantung pada banyaknya golongan senyawa yang terkandung.

\section{KESIMPULAN}

Penelitian ini menunjukkan bahwa ekstrak etanol $80 \%$ buah pare memiliki aktivitas sitotoksik yang tidak poten. Fraksi etil asetat mempunyai aktivitas sitotoksik yang paling besar dengan persentase penghambatan $43,87 \%$ sedangkan fraksi etanol dan n-heksana memiliki persentase penghambatan yang sama terhadap populasi sel MCF-7 yaitu 22,80\%.

\section{UCAPAN TERIMA KASIH}

Ucapan terima kasih kepada laboran Laboratorium Kultur Sel Mamalia, Bagian Biologi Farmasi, Fakultas Farmasi UMS, Ibu Rela Religia, A.Md, yang telah mendampingi dan banyak membantu selama jalannya penelitian ini.

\section{Daftar Pustaka}

Afifah U.N., 2017, Uji Aktivitas Atidiabetes Ekstrak Etanol 96\% Buah Pare (Momordica charantia L.) terhadap Tikus Jantan Galur Wistar yang Diinduksi Aloksan, Publikasi Ilmiah, Fakultas Farmasi Universitas Muhammadiyah Surakarta

Ainia N., 2017, Uji Fitokimia Infusa Pekat Buah Pare (Momordica charantia L.) dan Pengaruh Lama Terapi dengan Variasi Dosis Terhadap Penurunan Kadar Glukosa Darah Tikus (Rattus norvegicus) yang Diinduksi Aloksan, Skripsi, Central Library of Maulana Malik Ibrahim State Islamic University of Malang

Andersen Ø.M. and Markham K.R., 2005, Flavonoids: Chemistry, Biochemistry and Applications, CRC Press Taylor \& Francis Group, New York.

Arnani M., 2018, Obat Kanker Dihentikan Penjaminannya, Ini Jawaban BPJS Kesehatan Kompas.com, Kompas Media Terdapat di: https://megapolitan.kompas.com/read/2018/07/18/07000081/obat-kanker-dihentikanpenjaminannya-ini-jawaban-bpjs-kesehatan [Diakses pada February 5, 2019].

Budrat P. and Shotipruk A., 2008, Extraction of Phenolic Compounds from Fruits of Bitter Melon (Momordica charantia) with Subcritical Water Extraction and Antioxidant Activities of These Extracts, Chiang Mai Journal of Science, 35 (1), 123-130.

Comşa Ş., Cîmpean A.M. and Raica M., 2015, The Story of MCF-7 Breast Cancer Cell Line: 40 Years of Experience in Research, Anticancer Research, 35 (6), 3147-3154.

Dandawate P.R., Subramaniam D., Padhye S.B., Anant S., Physiology I., City K., City K., City K. and Campus A., 2017, Bitter Melon: A Panaceae for Inflamation and Cancer, HHS Public Access, 14 (2), 913-945.

Departemen Kesehatan Republik Indonesia, 2013, Formularium Nasional 2013, Dalam Departemen Kesehatan Republik Indonesia, Jakarta, pp. 1689-1699. 
Farnsworth N.R., 1966, Biological and Phytochemical Screening of Plants, Journal of Pharmaceutical Sciences

Fodor, T., Szántó, M., Abdul-Rahman, O., Nagy, L., Dér, Á., Kiss, B. and Bai, P., 2016. Combined treatment of MCF-7 cells with AICAR and methotrexate, arrests cell cycle and reverses Warburg metabolism through AMP-activated protein kinase (AMPK) and FOXO1. PLoS One, 11(2), p.e0150232.

Chen, C.R., Liao, Y.W., Wang, L., Kuo, Y.H., Liu, H.J., Shih, W.L., Cheng, H.L. and Chang, C.I., 2010. Cucurbitane triterpenoids from Momordica charantia and their cytoprotective activity in tert-butyl hydroperoxide-induced hepatotoxicity of HepG2 cells. Chemical and Pharmaceutical Bulletin, 58(12), pp.1639-1642.

Huang H.L., Hong Y.W., Wong Y.H., Chen Y.N., Chyuan J.H., Huang C.J. and min Chao P., 2008, Bitter Melon (Momordica charantia L.) Inhibits Adipocyte Hypertrophy and Down Regulates Lipogenic Gene Expression in Adipose Tissue of Diet-Induced Obese Rats, British Journal of Nutrition, 99 (2), 230-239.

Jia S., Shen M., Zhang F. and Xie J., 2017, Recent Advances in Momordica charantia: Functional Components and Biological Activities, International Journal of Molecular Sciences, 18 (12)

Junedi S., Sarmoko, Ikawati M. and Meiyanto E., 2009, Prosedur Tetap Panen Sel, (CCRC) Cancer Chemoprevention Research Center Farmasi UGM, 1-3.

Kementrian Kesehatan Republik Indonesia, 2018, Panduan Pelaksanaan Hari Kanker Sedunia 2018, Jakarta.

Liaw C.C., Huang H.C., Hsiao P.C., Zhang L.J., Lin Z.H., Hwang S.Y., Hsu F.L. and Kuo Y.H., 2015, 5 $\beta$,19-Epoxycucurbitane Triterpenoids from Momordica charantia and Their Anti- Inflammatory and Cytotoxic Activity, Planta Medica, 81 (1), 62-70.

Putri H., 2013, Protokol Uji Sitotoksik Metode MTT, CCRC (Cancer Chemoprevention Research Center) Fakultas Farmasi UGM, 1-8.

Raina K., Kumar D. and Agarwal R., 2016, Seminars in Cancer Biology Promise of Bitter Melon (Momordica charantia) Bioactives in Cancer Prevention and Therapy, Seminars in Cancer Biology, 40-41, 116-129. Terdapat di: http://dx.doi.org/10.1016/j.semcancer.2016.07.002.

Richmond R.A., Vuong Q. V. and Scarlett C.J., 2017, Cytotoxic Effect of Bitter Melon (Momordica charantia L.) Ethanol Extract and Its Fractions on Pancreatic Cancer Cells in vitro, Exploratory Research and Hypothesis in Medicine, 2 (4), 1-11. Terdapat di: http://www.xiahepublishing.com/ArticleFullText.aspx? sid=2\&jid=2\&id=10.14218\%2FE RHM.2017.00032.

Saifudin A., 2014, Senyawa Alam Metabolit Sekunder Teori, Konsep, dan Teknik Pemurnian, Deepublish.

Sudoyo A., 2017, Melantun Kebersamaan Berantas Kanker, Yayasan Kanker Indonesia, 69. 
Supraja P. and Usha R., 2013, Antibacterial and Phytochemical Screening from Leaf and Fruit Extracts of Momordica charantia, International Journal of Pharma and Bio Sciences

Thomasset S.C., Berry D.P., Garcea G., Marczylo T., Steward W.P. and Gescher A.J., 2007, Dietary Polyphenolic Phytochemicals - Promising Cancer Chemopreventive Agents in Humans? A Review of Their Clinical Properties, International Journal of Cancer, 120 (3), 451-458.

Vishwanath, Shobha Cr P., Mn S., Prashant A. and Rangaswamy C., 2015, In Vitro Anti Cancer Activity of Ethanolic Extract of Momordica charantia on Cervical and Breast Cancer Cell Lines, International Journal of Health and Allied Sciences, 4, 210-7.

Wang X., Sun W., Cao J., Qu H., Bi X. and Zhao Y., 2012, Structures of New Triterpenoids and Cytotoxicity Activities of the Isolated Major Compounds from the Fruit of Momordica charantia L., Journal of Agricultural and Food Chemistry, 60 (15), 3927-3933.

Wardhani L.K. and Sulistyani N., 2012, Uji Aktivitas Antibakteri Ekstrak Etil Asetat Daun Binahong (Anredera scandens (L.) Moq.) terhadap Shigella flexneri Beserta Profil Kromatografi Lapis Tipis, Jurnal Ilmiah Kefarmasian, 2 (1), 1-16.

Yin, J., Zhang, H. and Ye, J., 2008. Traditional Chinese medicine in treatment of metabolic syndrome. Endocrine, Metabolic \& Immune Disorders-Drug Targets (Formerly Current Drug Targets-Immune, Endocrine \& Metabolic Disorders), 8(2), pp.99-111.

Zahrah A., Kusmardi and Sunaryo H., 2018, Uji Sitotoksisitas Fraksi Etil Asetat Ekstrak Etanol 70\% Buah Pare (Momordica charantia L.) terhadap Sel HeLa, Farmasains, Fakultas Farmasi dan Sains Universitas Muhammadiyah Prof. Dr. Hamka 